\title{
TIME FOR TEACHERS AND STUDENTS TO TAKE MORE CONTROL OF LEARNING
}

\author{
Authors: \\ Simona Laurian-Fitzgerald \\ University of Oradea (Romania) \\ Carlton J. Fitzgerald \\ New England College (USA) \\ The address of the first author: \\ mmonalaurian@yahoo.co.uk
}

Maria Cristina Florescu (Ph.D.)

University of Oradea (Romania))

Laurian-Fitzgerald, Simona \& Fitzgerald, Carlton J. (2021). Time for Teachers and Students to take More Control of Learning. Különleges Bánásmód, 7. (1). 85-90. DOI 10.18458/KB.2021.1.85

\begin{abstract}
The article focuses on the idea that it is time that teachers and students take control of their own learning, that education must be transformed and aligned the realities of 21 st century. One way to take ownership of our own learning is student-centered teaching and learning. In this process several elements are important: constructivist activities, metacognitive reflections, student and professor partnerships, collaborative/cooperative efforts, authentic assessments, active and on-going student engagement in the work to learn, explicit teaching of important skills, student control of at least some of their learning, peer and professor/teacher feedback, and learning based, to a large extent, on student effort.
\end{abstract}

Keywords: student-centered teaching and learning, education reform, successful learning

Discipline: pedagogy

\begin{abstract}
Absztrakt
IDEJE, HOGY A TANÁROK ÉS A DLÁKOK JOBBAN KONTROLLÁLJÁK A TANULÁST

A tanulmány fókuszában az áll, hogy itt az ideje, hogy a tanárok és a diákok irányítsák a saját tanulási folyamatukat, valamit az oktatást át kell alakítani és összehangolni a 21. század valóságával. Az egyik lehetőség a saját tanulási folyamatunk ellenőrzésére a diákközpontú tanulás és tanítás. A folyamatban számos összetevő játszik szerepet: konstruktivista tevékenységek, metakognitív reflexiók, diák-tanár partneri viszony, együttmúködési erőfeszítések, hiteles értékelés, a diákok aktív és folyamatos bevonása a tanulási folyamatba, a fontos készségek explicit tanítása, a diákok legalább a tanulási folyamatuk egy részének irányítói, kortárs és professzori/tanári/oktatói visszajelzés, valamint nagymértékben tanuláson alapuló tanulói erőfeszítés.
\end{abstract}

Kulcsszavak: tanulóközpontú tanítás és tanulás, oktatási reform, sikeres tanulás

Diszciplína: pedagógia 


\section{Introduction}

For at least 25 years people having been trying to reform education. By many accounts, in spite of great efforts by well-intentioned politicians, business people, educational leaders, reformers, and teachers, the reform movement has not worked. Wagner (2014) believes that even our best schools are doing an inadequate job of preparing students for their future lives. Sir Ken Robinson (2017) not only agrees with Wagner, but also believes that education can no longer be reformed. $\mathrm{He}$ and others believe that education must be transformed. Sousa (2017) relates how teaching and learning must be more aligned with how the brain learns, and that the accountability mentality of the past 25 years is not aligned with students' brains. Geraghty (2020) relates that his students are tired of the mentality of accountability and conformity that exists in so many schools today. His students say they want more meaningful work in their classes. Students are not afraid of hard work, but they are sick and tired of regurgitating back to teachers what they believe teachers want. Instead these students want to work toward their goals in life in their classes today.

Caine (2018) explains how students should be taught to move from dependent learners to independent learners. Laurian-Fitzgerald and Fitzgerald (2019) describe how students have reacted to the techniques used to help the teaching and learning process to be more student-centered. Students should not be forced to comply to school; they should not be asked to regurgitate information that can mush more easily be found on the internet in five to ten seconds; they should not be asked to do mundane work; students should not be doing work that cannot be related to the real world I significant ways. Caine et al. (2016) explain how students should be taught to take more and more control of their learning, while teachers should be learning how to move from professors of knowledge to mentors of students who are working on their own life goals.

These ideas, of course, mean that students and teachers must learn new roles in the process of teaching and learning. If the teaching and learning process is going to become more collegial, then adults and students must learn new roles. Many students are not going to want to play this new game of schooling, because they have learned to be comfortable in the old game of schooling. That is, many students have become very comfortable getting good grades while putting forth a minimal effort. These students will not be happy, at first, when they are being asked to work harder, to be more responsible for their learning, and to be more responsible for other students around them. As one student put it, "Just give me the work and then the test and leave me alone." As Davison (2017) relates, these students have no idea how unprepared they are for what they will face upon graduation. And he tells us that parents and teachers do not understand what we are not doing for and with our students.

In what Caine (2018) calls the tier three pedagogy, students must learn to be advocates for their learning and teachers must learn to be advisors, guides, and mentors for their students. Too many teachers, too, have become very comfortable playing the old game of schooling. Their lessons and units have been set for years, and even though they know that a percentage of their students are failing or under achieving, they continue to teach the same things in the same ways, getting the same results. We can no longer afford to allow so many students to be uneducated or undereducated. Robinson (2017) explains that our world can no longer afford to lose the skills, talents, and passions of so many young people.

Teachers must be willing to learn new pedagogical philosophies and techniques to help their students find their talents and passions, and, to develop them to their fullest extent. We must 
learn to help students find and develop their voices. Teacher must learn how to inspire students instead of forcing students to comply. When teachers inspire students they will want to work hard, not to get good grades, but for their love of learning. Csikszentmihalyi (1990; 2008) writes about flow, the state of being totally engaged in what one is doing. When someone is in flow, two hours seems like ten minutes. Teachers can learn to develop experiences in which students are engaged in activities about which they are passionate. Then, students will not ask about the time, they will ask for more time to work. The goal is not to get all of the students to learn the material for the test, the goal will be to help students inspire themselves to learn more and more.

This must begin by making sure teachers know and understand our students. How do we do that—ask our students. Ask students what they are interested in doing in school, outside of school, in their future lives, in their hobbies, etc. Use what ever techniques help a teacher gain that information: interviews, surveys, journals, cooperative activities, student-generated projects, field trips, investigations, etc. There are so many ways for teachers to learn about students and their talents, dreams and goals. The first step is to decide that student-centered teaching and learning is more important than testing. Ravitch (2016) believes that educators have been brainwashed into believing that all students should learn the same things, in the same way, and be assessed with single-time standard assessments. She states that despite the lack of evidence, those in charge still maintain that standardized testing leads to higher achievement. She too was brainwashed into believing the fantasy of testing, but now has changed her ideas. She advocates that the rest of us should look at the reality of life, and understand that learning should be centered on students and their interests, skills, passions, and dreams.

Laurian-Fitzgerald, Popa, and Fitzgerald (2015) also discuss the idea that educators are rushing into getting students to pass tests instead of helping students become the people they should become. Helping students become the great people they can and should be is much more important than passing a standardized test. Instead of trying to make students learn about the game of schooling, teachers should be helping students to learn about the game of life. As Dewey (1910) has told the world of education, everything students learn should help them in the real world in some important way. The social and emotional sides of our students are important for learning. According to the Berkley Unified School District (Toolbox: Social Emotional, 2020):

Years of research in the field of childhood resiliency and social-emotional learning have taught us that emotional and behavioral regulation skills can be explicitly taught in schools and that the benefits are huge!

Significant data from 213 studies indicates that SEL programs are associated with positive results:

- Improved attitudes about self and others,

- Increased pro-social behavior,

- Lower levels of problem behaviors and emotional distress, and

- Improved academic performance (Catalano et al., 2002; Greenberg et al., 2003; Zins et al., 2004).

Instead of rushing headlong into the flame of testing and accountability, educators should be working with students to become the best they can be.

\section{Student-Centered Teaching and Learning}

In order to move toward this idea of studentcentered teaching and learning there are some basic assumptions that teachers should consider:

- All students have great potential.

- All students can learn well. 
- Diversity is the natural state of life, and that diversity should be embraced.

- Each student is a unique learner and person.

- School should be about helping all students reach their potentials.

Teaching and learning should be centered on students, not on politicians, not on tests, not on helping the powerful remain powerful and the weak remain weak. Education should be about human freedom, the ability to make one's own choices and reach one's own goals and dreams in life.

So, how do we begin this process of being student-centered? Laurian-Fitzgerald and Fitzgerald (2019) have developed 10 elements for beginning the process of student-centered teaching and learning. In their work they have found that students are very willing to work hard, to push themselves and their instructors, and to help their colleagues do the same. The following ideas are not an exhaustive list, rather they are beginning thoughts for teachers to ponder. In our classes we have become convinced that we can develop programs and experiences with and for students that include:

1. constructivist activities,

2. metacognitive reflections,

3. student and professor partnerships,

4. collaborative/cooperative efforts,

5. authentic assessments,

6. active and on-going student engagement in the work to learn,

7. explicit teaching of important skills,

8. student control of at least some of their learning,

9. peer and professor/teacher feedback, and

10. learning based, to a large extent, on student effort.

This is a dynamic process, and it can be messy, but the rewards of watching students grow as we all struggle to make it work is so inspiring to us. As one student said, "You teach with your heart, and that makes all of the effort worth it."

The goal of becoming student-centered begins with a commitment on the part of teachers to change how and what we teach. It begins with a first tiny step. Anything worthwhile, takes a great deal of time and effort, and it goes one step at a time. A good place to begin might be in the setting of the classroom environment (for example, Maslow (1970; 1971) and Glasser (1998) have both developed ideas about the basic needs of human beings. Fitzgerald and Laurian (2013) have added to those ideas to help set a classroom that is safe emotionally and physically, caring, joyful, and empowering, that embraces all people, and where students do meaningful work with their peers and individually. Maslow (1971) and Duckworth (2016) also discuss how students who do for others grow in their passions and in their personhood-they become more positive and cooperative people.

Laurian-Fitzgerald, Popa, and Fitzgerald (2015) also have developed a philosophical overview for student-centered teaching and learning. If we are becoming more successful in our attempts to be student-centered, we will see more students who:

1. become successful learners.

2. are actively engaged in their learning.

3. make as many choices as possible in their learning.

4. work positively and regularly with other students in a variety of ways.

5. are encouraged to be curious.

6. do meaningful work most of the time they are in school.

7. work on complex projects both individually and in teams.

8. become independent workers, as well as good teammates.

9. integrate the arts as an important part of their learning experiences.

10. set goals for their own learning. 
11. are supported to take intelligent risks in their learning.

12. understand that learning depends on great strategic efforts.

13. understand their place in the world.

14. develop fair-mindedness, empathy, and understanding in their work with and about other people.

15. are supported in their efforts socially and academically by their peers and by their teacher.

16. work in a positive and supportive ways with their colleagues.

This is the beginning of the process. It will take plenty of work. There will be missteps and frustrations, but there will also be huge successes. Many teachers have already begun this process, so we are not alone. Together one classroom at a time, we will make a huge difference for our students. It is time for students and teachers to take back education for all of those people who think they know better than we do. We are educators, that is who we are, and we need together to make schooling what it should be-a place where all students find success and create a path for successful lives after graduation.

\section{References}

Caine, G. (2018). Making connections between elearning and natural learning. In C. Fitzgerald, S. Laurian-Fitzgerald, \& C. Popa (Eds). Handbook of research on student-centered strategies in online adult learning environments. Hershey, PA: IGI Global.

Caine, R. N., Caine, G., McClintic, C. L., \& Klimek, K. L. (2016). 12 brain/mind learning principles in action: Teach for the development of higherorder thinking and executive function (third edition). Thousand Oaks, CA: Corwin.
Catalano, R. F., Berglund, M. L., Ryan, J. A. M., Lonczak, H. S., \& Hawkins, J. D. (2002). Positive youth development in the United States: Research findings on evaluations of positive youth development programs. Prevention \& Treatment, 5(1), Article 15. doi. 10.1037/1522$\underline{3736.5 .1 .515 \mathrm{a}}$

Csikszentmihalyi, M. (1990; 2008). Flow: The psychology of optimal experience. New York, NY: Harper Perennial Modern Classics.

Davidson, C. N. (2017). The new education: How to revolutionize the university to prepare students for a world in flux. New York, NY: Basic Books.

Dewey, J. (1910). How we think. Boston, MA: D.C. Heath Publishers.

Duckworth, A. (2016). Grit: The power of passion and perseverance. New York, NY: Scribner.

Fitzgerald, C., \& Laurian, S. (2013). Caring our way to more effective learning. In Procedia-Social and Behavioral Sciences, 76(2013) 341-345.

Geraghty C. (2020). A Call for Change from Within the Classroom. In From the Inside-Out: Concrete Steps to Transforming Education Today. Andrusiak, R.A., Bastoni A., Fitzgerald C.J., Geraghty, C., Laurian-Fitzgerald, S., PetrunoGoguen, R. (eds.) Maryland: Rowman \& Littlefield.

Glasser, W. (1998). Choice theory: A new psychology of personal freedom. New York, NY: HarperCollins.

Greenberg, M. T., Weissberg, R. P., O'Brien, M. U., Zins, J. E., Fredericks, L., Resnik, H., \& Elias, M. J. (2003). Enhancing school-based prevention and youth development through coordinated social, emotional, and academic learning. American Psychologist, 58(6-7), 466474. doi. 10.1037/0003-066X.58.6-7.466

Laurian-Fitzgerald, S., Fitzgerald, C. (2019). Student Centered Learning in Undergraduate Preservice Teachers. Volume LXVII, Pages 1 2235, The European Proceedings of Social \& Behavioural Sciences. Future Academy. 
Laurian-Fitzgerald, S., Popa, C., \& Fitzgerald, C. J. (2015). The race to reach standards: Are we forgetting about our students? Romanian Journal of School Psychology. 8 (16).

Maslow, A. H. (1970). Motivation and personality. New York, NY: Harper \& Row.

Maslow, A. H. (1971). The farther reaches of buman nature. New York, NY: The Viking Press.

Ravitch, D. (2016). The death and life of the great American school system: How testing and choice are undermining education. New York, NY: Basic Books.

Robinson, K. (2017). Out of our minds: The power of being creative (3rd ed.). Chichester, United
Kingdom: John Wiley \& Sons, Incorporated.

Sousa, D. A. (2017). How the brain learns (5th ed.). Thousand Oaks, CA: Corwin.

Toolbox: Social Emotional Learning Curriculum for K-6

Students. (2020). Available online at: https://www.berkeleyschools.net/teachingand-learning/toolbox/

Wagner, T. (2014). The global achievement gap: Why even our best schools don't teach the new survival skills our children need and what we can do about it. New York, NY: Basic Books.

Zins J. E., Weissberg, R. P., Wang M. C., Walberg H. J. (Eds). (2004). Building Academic Success on Social and Emotional Learning: What Does the Research $S$ 